\title{
CDK9 wt Allele
}

National Cancer Institute

\section{Source}

National Cancer Institute. CDK9 wt Allele. NCI Thesaurus. Code C126981.

Human CDK9 wild-type allele is located in the vicinity of $9 q 34.1$ and is approximately $5 \mathrm{~kb}$ in length. This allele, which encodes cyclin-dependent kinase 9 protein, is involved in protein phosphorylation and the regulation of transcription. 